Агнешка Сова - Кофта

Институт за трудови и социјални студии, Варшава, Полска

\title{
ОДГОВОРОТ НА КОВИД-19 ВО РЕЗИДЕНЦИЈАЛНАТА ДОЛГОРОЧНА НЕГА ВО ПОЛСКА: ШТО Е НАПРАВЕНО ЗА ПОДОБРУВАЊЕ НА БЕЗБЕДНОСТА НА ПОСТАРИТЕ ЛИЦА
}

\section{Вовед}

Полското општетсво се заснова врз традиционални, фамилијарно-ориентирани вредности, и покрај присуството на различни долгорочни програми за нега, секторот на јавно финансирана и обезбедена нега на повозрасните лица, лицата со инвалидитет и зависните лица не е добро развиен, во споредба со Западно европските држави. Шатур Јаворска (Szatur-Jaworska) (2018) заклучува дека негата на стари лица тешко се препознава и се обработува во јавната дебата како систем којшто повеќе го сочинуваат политики и програми во социјалниот и во здравствениот сектор, ориентирани на поддршка на повозрасните лица, лица со инвалидитет или зависните лица, како и нивните негуватели. Кон крајот на 70-тите и 80-тите години од 20-тиот век, се одржа јавна дебата во врска со потребите на постарата популација концентрирани на поддршка на приходот и пристапот до старосна пензија, перцепцијата на улогата на старите лица во општеството и обезбедувањето пристап до установите за згрижување стари лица (Сзатур-Јаворска 2016). Кога диску- сијата за стареењето на населението започна во доцните 1990-ти, креаторите на политики беа фокусирани на преуредување на пензискиот систем (од системот „принцип на генерациска солидарност-финансирање на тековна основа- Рay as you go“ во систем на дефинирани придонеси) (Голиновска, Сова-Кофта 2017). Само во втората деценија на 2000-тите години беше посветено поголемо внимание на другите форми, освен на формите поврзани со приходите на поддршка за постари луѓе. Кога започна политиката за постарите луѓе во 2013 година - по Европската комисија во 2012 година, како европска година на старосна структура и солидарност меѓу генерациите - тоа беше стимул за преземање повеќе активности кон постарите лица, особено насочени кон зголемување на ангажманот на локалните заедници во создавањето услови за активирање на постари лица. Второто беше поддржано со владината програма за грантови за невладина организација, т.н. Програма за социјална активност за стари лица (Program Aktywności Społecznej Osób Starszych 
- ASOS). Во 2018 година беше усвоена нова владина политика со наслов „Социјална политика за старите луѓе“, со повеќе фокус на социјалните потреби на старите лица, вклучително и грижа во различни форми (Шатур-Јаворска 2018- Szatur-Jaworska 2018).

Услугите и придобивките насочени кон грижата за постарите лица се воведени добро со самата политика, зацврстена во регулативата за основните одредби на здравствениот систем и социјалната помош. Различни услуги и бенефиции за долгорочна нега се доделуваат во рамките на јавно финансираниот здравствен систем, социјална помош и социјалното осигурување. Во принцип, паричните надоместоци - т.н. додаток за нега - се доделуваат од социјално осигурување универзално, за сите граѓани опфатени со социјално осигурување кои достигнуваат 75 или повеќе години. Дополнително, на оние кои не се опфатени со социјалното осигурување, може да им се додели медицинска помош со систем на семејни надоместоци, финансиран од централните даноци.

Услугите за домашна нега можат да бидат доделени од локалната самоуправа и од службата за социјална помош. Сепак, околу една третина од локалните власти не даваат ваков вид услуги бидејќи не се задолжителни и зависат од можноста на локалните власти да ги обезбедат. Слично на тоа, локалните власти можат да обезбедат специјализирани услуги за нега, вклучително и услуги за лица со психијатриски нару- шувања. Услугите за нега во домашни услови се обезбедуваат врз основа на одлука на лекар од примарна здравствена заштита во рамките на заедницата. Со медицинските сестри управуваат единиците на примарната здравствена заштита и финансиите од здравственото осигурување.

Услугите во установи за згрижување стари лица, исто така, се доделува на граѓаните во рамките на здравствениот систем и системот за социјална помош. Институционалните услуги за медицинска нега и за грижа се достапни за луѓе во најтешки здравствени услови (проценети како 40 поени или подолу по скалата Бартел) и финансирани од здравствено осигурување. Згрижувањето во домовите од категоријата на социјална помош е достапна за луѓе за кои семејството не е во можност да обезбеди грижа и на кои им е потребна помош во нивните активности. И покрај различните видови услуги, нивната употреба е мала. Проценките покажуваат дека помалку од $1,1 \%$ од постарите лица се згрижуваат во јавни згрижувачки институции или во здравствениот или во социјалниот сектор.

Епидемијата на Ковид-19 изврши притисок врз долгорочната нега на стари лица од првите недели на пандемијата. Како и во повеќето европски земји, особено во Соединетите Држави и Канада, установите за згрижување и нега на стари лица беа во опасност од епидемија и од нејзините негативни последици, вклучително и смрт на згрижени лица. Пандемијата веднаш 
и болно ги отсликува слабостите на системот за долгорочна нега. Во написот се презентирани информации за епидемијата Ковид-19 во Полска и се дискутираат методите донесени за да се одговори на епидемијата во установите за долгорочно згрижување и нега во првите месеци од пандемијата.

\section{Епидемија со Ковид-19 во Полска}

Првиот случај на Ковид-19 беше дијагностициран во Полска во првата недела од март 2020 година, неколку недели по избувнувањето во Западна и Јужна Европа. Првите случаи не беа поврзани со лица во старски домови, но беа дијагностицирани кај туристи кои се враќаa од Германија и Италија, но веќе беа пријавени случаи на болници и во старски домови во средината на март. Владата одлучи да ја блокира економијата и да ја ограничи мобилноста, како и да промовира физичко и социјално дистанцирање како непосреден одговор на епидемијата, со што бројот на случаи растеше умерено, достигнувајќи 2,2 илјади до крајот на март. Сепак, треба да се забележи дека оттогаш бројот на случаи постојано расте, со најголема нагорна крива во октомври, достигнувајќи над 149 илјади случаи/ вкупно 3308 смртни случаи и дневно зголемување од 8,1 илјади случаи на 15 октомври.

Постарите луѓе претставуваат голем дел од прикажаните случаи и воглавно сериозно претрпеа негативни последици од болеста, вклучително и смрт.
Податоците достапни на крајот на мај, по два месеци од пандемијата, покажаа дека луѓето на возраст од и над 65 години претставуваа околу $80 \%$ од сите смртни случаи од Ковид-19 и луѓе на возраст од и над 80 години, околу $44 \%{ }^{1}$.

\section{На кој начин беше засегната негата на стари лица?}

Следењето на бројот на инфекции кај установите за долгорочна нега на стари лица е тешко бидејќи официјално објавените податоци не упатуваат на инфекции според нивниот извор, а системот за известување се менувал неколкупати во текот на месеците по избувнувањето. Исто така, процедурите во врска со пристапот до тестовите за SARS-Co-2 се менуваат со текот на времето, што има влијание врз бројот на дијагностицирани случаи.

Првите случаи на Ковид-19 во институциите за долгорочна нега на стари лица беа дијагностицирани во средината на март и беа опширно покриени од медиумите поради проблемите што веднаш се појавија. Негувателиштата беа крајно неподготвени за пандемијата. Најчесто пријавуваните проблеми беа поврзани со слаб пристап до тестови за SARS-Co-V-2 во просториите на Установите за долгорочна нега и проблеми со обезбедување на изолација на пациентите, особено на лица, во установите. Причините за инфекции се различни,

\footnotetext{
Следниве информации се објавени на Твитер од страна на Министерството за здравство.
} 
но беа слични на пријавените во други земји и вклучуваа недоволна, па дури и недостиг од заштитна опрема (маски, штитови, ракавици), недоволни превентивни процедури, како и повеќекратно вработување на медицински сестри кои често работат во болници и домови за згрижување. Беа пријавени и други проблеми, особено слаб пристап до здравствена заштита во домови за социјална помош. Студиите покажуваат дека пренесувањето на КОВИД-19 е предизвикано не само од симптоматски персонал или пациенти, туку и од асимптоматски членови на семејството или персоналот што ги прицврстува патиштата за пренесување на инфекцијата (Comas-Herrera et al. 2020, Комас-Epepa и сор. 2020). Во исто време, постарата и инвалидната популација е изложена на најголем ризик од негативни последици од инфекции, вклучително и смрт, поради повеќе здравствени проблеми. Симптомите на инфекција кај постарата популација може да варираат, вклучувајќи не само треска, диспнеа, туку и дијареја, проблеми со меморијата и делириум, губење на апетит и паѓање - повеќето од нив се типични за население кое живее во стари лица и домови за стари лица, а со тоа и болест уште потешко е да се разликува од другите болести.

Според податоците на Владата од почетокот на јуни 2020 година, околу 9\% од случаите на КОВИД-19 биле поврзани со инфекции во долгорочна помош во Полска: $3 \%$ во домови за стари лица и $6 \%$ во домови за со- цијална заштита (Rządowe Centrum Bezpieczeństwa 2020). Сепак, податоците за изворите на инфекции не се многу точни што укажуваат на голем удел на други (непознати) извори (41\%) и со зголемениот број на случаи потешките за откривање на изворите. Во летото, важноста на единиците за долгорочна нега како извор на инфекции се намалуваше додеека другите извори станаа истакнати: клубови и забави, свадби и инфекции во фабриките. Во септември, училиштето беше повторно отворено и економијата се врати во целост, што придонесе и за растечкиот број на случаи со КОВИД-19. До средината на октомври, КОВИД-19 беше пријавен во 113 домови за социјална помош, од околу 800. Бројот на домови за грижа и стари лица со пријавени случаи на КОВИД-19 не е покриен со јавно достапни податоци. Сепак, бројот на приватни установи за грижа со заразени пациенти не се следи, така што нема целосна слика за инфекции во станбената долгорочна нега.

Првите случаи на КОВИД-19 во домови за социјално ранливите категории и домовите за нега и згрижување на стари лица беа следени од страна на медиумите, известувајќи за повеќе проблеми. Поради фактот дека негата на стари лица е недоволно кадровски покриена, недостатоците во бројот на медицински сестри и негуватели брзо станаа очигледни во установите кои се бореа со инфекции. Во некои установи, персоналот мораше да работи дури и да пројави симптоми на КОВИД-19 би- 
дејќки немаше замена и имаше неколку случаи пријавени кога само малкумина од персоналот за нега останаа на своите места во установа, работејќи дење и ноќе. Административните тела се обидоа да мобилизираат персонал - медицински сестри и негуватели од други установи, но се бореа со тешкотии. Забележани се проблеми со изолирање на заразените лица и преместување на болни жители во болници. Постарите луѓе беа пријавени дека се збунети и честопати не сакаат да ги напуштаат установите. Во случаи на евакуација на жителите, армијата интервенираше да се преселат пациентите во болниците. На многу локации, локалната заедница поддржуваше негуватели во станбени домови, одгледувајќк храна, пијалаци и заштитна опрема (маски, ракавици), често домашно изработени. Со текот на времето, ситуацијата се подобруваше, особено во однос на пристапот до заштитна опрема и процедури, иако сѐ уште беа пријавени некои проблеми со преместување на пациенти во болници или недостиг од персонал, особено затоа што интензитетот на инфекцијата е во нагорна линија и бројот на легла во болниците за третман на пациенти со КОВИД-19 се намалува, како резултат на високата стапка на зафатеност.

\section{Реакција на ефектите од кризата во установите за нега на стари лица}

Пандемијата и нејзиното влијание врз долгорочната нега, стана едно од најсуштинските прашања во врска со пандемијата во средината на март. Децентрализацијата на одговорностите, при што локалните власти беа одговорни за домовите за социјална заштита како и поделбата помеѓу здравствената заштита и социјалниот сектор имаа негативно влијание врз брзата и сеопфатна реакција во однос на проблематиката. Кај домовите за социјална заштита, управувањето со кризата зависеше од можноста на локалните власти и менаџерите да ги мобилизираат ресурсите. Вклучени беа и невладини организации за инвалидни лица, кои лобираа за реакција на централните власти - Министерството за здравство и Министерството за семејство, труд и социјална политика.

На крајот, реакцијата дојде од повеќе тела: локалните власти организираа снабдување на установите за нега со пријавени случаи на КОВИД-19, подобрено управување со цел да се воведат мерки за превенција; централната влада одлучи да стави дополнителни финансиски средства за опремување на капацитети и за зголемување на надоместокот на медицинскиот персонал и на персоналот за нега во установите и во консултатските тела, во соработка со предвидената рамка во јавната администрација за воведување на превентивни процедури. Процедурите беа изготвени и објавени под надзор на Министерството за здравство и на Министерството за семејство, труд и социјална политика од страна на националниот консултант за инфективни болести и 
националните консултанти за медицинска нега, долгорочна медицинска нега и геријатриска медицинска нега. Препораките, објавени на почетокот на април, беа насочени кон зголемување на безбедноста на жителите во институциите за долгорочна нега и кон намалување на ризикот од пренесување на инфекција, како и зголемување на безбедноста на постарите и хронично болни лица во домашна нега и грижа.

Повеќето од овие препораки беа донесени како превентивни мерки од страна на установи за згрижување стари лица. Меѓу најважните, потенцијално со долгорочен ефект, се ограничу-

\section{Табела 1. Препораки издадени од страна на националниот консултант за инфективни болести ${ }^{1}$}

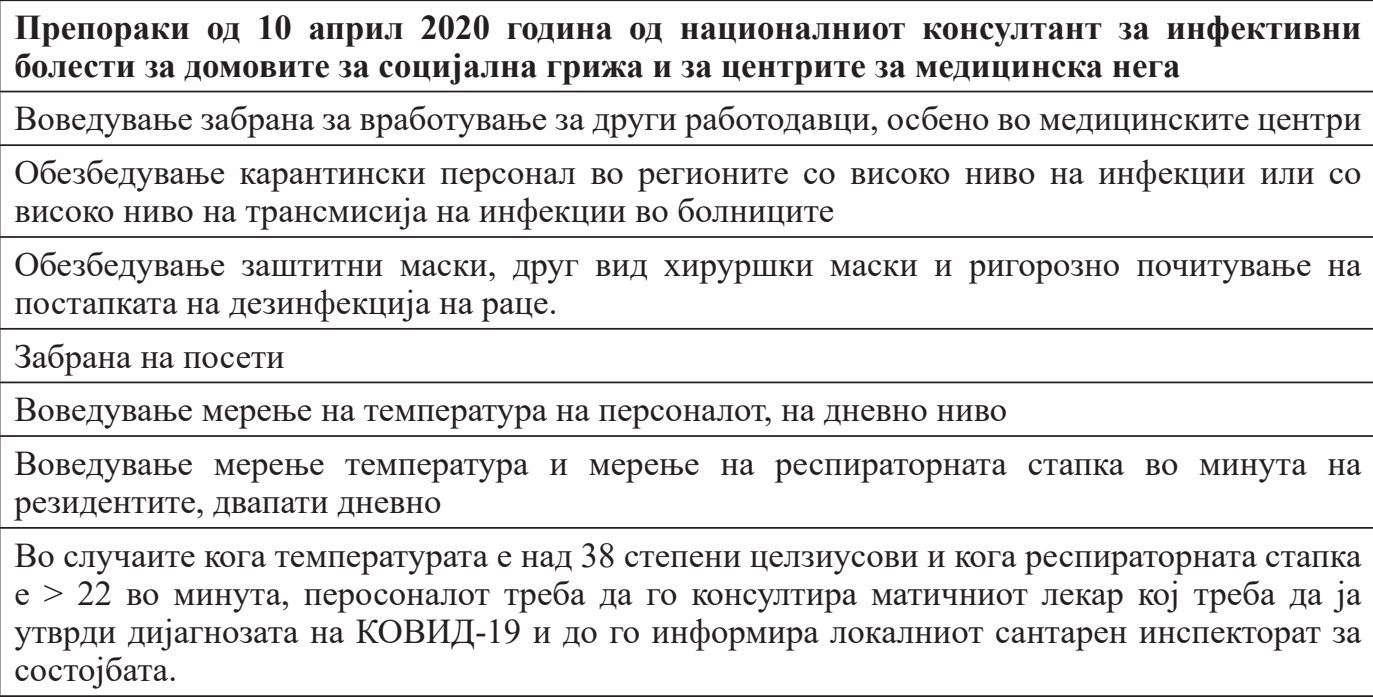

1 http://www.dps.pl/koronawirus/inne/zalecenia-krajowego-konsultanta-w-dziedzinie-chorobzakaznych-z-dnia-10042020-dla-dps-ow-i-jednostek-opiekunczo-leczniczych-22 
Табела 2. Препораки и организација на услуги на нега и грижа во секторот за долгорочна нега во однос на епидемијата и на ризикот од инфекција со вирусот SARS-CoV-1 и развојот од КОВИД-19, земајќи ги предвид препораките на Полската асоцијација за нега, националниот консултант во долгорочната медицинска нега и националниот консултант за геријатриска нега. ${ }^{1}$

Активности кои треба да се преземат во стационарите и во центрите за давање домашна нега за да се намали ризикот од пренос:

Рестрикција или забрана на посети на пациент кои се негуваат во домашните услови од страна на членови на семејството, пријатели и медицински персонал, како и комплетна забрана на посета на резиденти во институции

Ограничување на бројот на персонал (вклучувајќи го и медицинскиот персонал) кој работи директно со пациенти во установите за медицинска нега и грижа на пациенти до потребниот минимум:

-Во случај на поголемо одвојување на поголеми медицински субјекти на подтимови и по сектори за нега и одделенија

- $\quad$ Поради повисокиот ризик за пренос во домовите за нега на стари лица, се препорачува да се ограничи аутсорсинг (надворешни извори) и вработување на надворешни медицински лица и персонал за нега, за оние вработени во други медицински установи, сѐ до степенот до којшто дозволува системот за управување и епидемиолошка безбедност во однос на персонал и пациенти.

Промена на организацијата на работата на медицинскиот персонал вработен во старските домови и домовите за нега кои имаат паралелно врабоување во други медицински одделенија (во посебни болници) со имлементирање работа од далечина и со користење Информациско-комуникациски системи за консултации на пациенти кои примаат нега во старските домови.

Доколку постои потреба од личен совет/ консултација/ преглед на пациент кој е сместен во старски дом, треба да му биде обезбедена максимална епидемиолошка заштита.

Информирање и едуцирање на семејства на пациенти кои примаат нега во старски домови, како и пациенти кои имаат потреба од социјална дистанца поради хронична болест, вклучувајќи и потреба за елиминирање контакти на пациенти од старски домови со лица кои биле на потенцијално ризични места и кои се професионално активни и кои може да бидат потенцијален извор на инфекција поради природата на нивната работа (јавна администрација, трговски работници)

\section{Превентивни мерки во установите за нега на стари лица:}

Раководните органи треба да обезбедат едукација на персонал во однос на личната хигиена, хигиена на раце и можноста за пренесување на вирусот SARS-CoV-2 кој го предизвикува КОВИД-19 (индивидуална обука, електронска обука, видео-презентации со насоки, постери) како и користење на заштитна облека (правилно ставање, безбедно отстранување). Надградување на информациите за хигиена и за одвојување на работната од домашната средина.

1 https://www.gov.pl/web/zdrowie/zalecenia-dotyczace-organizacji-procesu-udzielania-swiadczenpielegnacyjnych-i-opiekunczych-w-ramach-opieki-dlugoterminowej2 
Редовна проверка на пораки од Главниот санитарен инспектор и од Министерството за здравство за да се следат промените во епидемиолошката состојба предизикани од вирусот SARS-CoV-2 и да се следат правилата за квалификување на пациенти за понатамошни постапки за во случај на контакт со лица суспектни на инфекција. Случаите кои ги исполнуваат симптомите за можност од инфекија треба да се пријават кај санитарниот инспекторат.

Пред работа со пациенти, медицинскиот персонал кој обезбедува долгорочна нега во старски домови треба да изврши самоконтрола со мерење телесна температура додека во домовите за долготрајни нега на постари лица се врши од страна на овластена медицинска сестра, шеф на одделение или назначена сестра на должност. Резултатите од мерењето треба да се евидентираат во медицинската документација.

Во установите за згрижување постари лица, изолацијата на лицата кои се можно заболени од КОВИД-19 треба да се обезбеди (со пристап до тоалет, опремени со лична заштита, термометар, средства за дезинфекција на раце и на средината) со што би се обезбедил безбеден престој во установата, со поддршка на медицински лекар или сестра, до доаѓањето на санитарниот тим за транспорт.

Да се има предвид дека лицата сместени во установите за долгорочна нега на постари лица поради пандемијата се лишени од директна поддршка и присуство на роднини/ неформални негуватели и истовремено не може да ги продолжат своите контакти преку телефон или интернет, и персоналот за нега е обврзан да им го обезбеди тоа поради нивната осаменост, со запазувањее на највисоки стандарди на нега и емоционална поддршка.

Личната заштитна опрема треба да се користи во согласност со епидемиолошките препораки за ограничување на ширењето на вирусот SARS-CoV-2 и на болеста КОВИД-19, земајќи го предвид достапниот персонал, условите и обемот на активности.

Секој кој работи во установи за долгорочна нега треба ги применат сите мерки на претпазливост и да ги преземат сите едукативни и превентивни мерки за да се намали ризикот од вирус SARS-CoV-2 и COVID-19.

Медицински брифинзи, организациски состаноци и консултации помеѓу членови од тимот треба да се одржуваат во телекомуникациска форма.

Треба да се користат сите достапни, сигурни извори за вирусот SARS-CoV-2 и КОВИД-19, на пример на веб-страницата на Одделот за социјална медицина и јавно здравје на Медицинскиот универзитет во Варшава, во табулаторот за билтени, има неделна презентација за коронавирусот упатена до медицински професионалци и негуватели.

Менаџерите за нега и за персоналот треба да назначат координатор одговорен за стекнување и за ажурирање на знаењето, сукцесивно и систематско предавање на знаењето на персоналот, како и за зголемен надзор над работата на персоналот во областа на спроведување на принципите за лична заштита и заштита на трошоците, и за зајакнување на нивното здравје.

Со цел да се одржи епидемиолошка безбедност, потребно е да се повлече од групните часови на работна терапија, кинезиотерапија, заеднички оброци во мензата, итн. Часовите треба да бидат ограничени на простории за пациенти и рехабилитација до апсолутно посочениот основен опсег. Третмани и вежби за рехабилитација треба да се спроведуваат индивидуално во кревет и/или во одделот. 
Поради фактот дека инфективноста на вирусот SARS-CoV-2 веројатно започнува кратко време пред појавата на симптомите на болеста КОВИД-19 и продолжува сѐ додека не се започне со нивно решавање и се појавува атипично инфективна болест кај постари лица и пневмонија, кај пациенти кај кои сѐ уште не дијагностициран со сериозно когнитивно оштетување, треба да се обрне внимание на симптомите на делириум (како што се: промени во однесувањето, влошување на вербално-логички контакт, неконзистентно размислување, недостиг од концентрација, неможност да се одговори на прашања, конфузија, прекумерна поспаност, слабост или претходно незабележано нарушување) и да се утврдат знаци на КОВИД-19.

Охрабрување и овозможување на жителите да останат во далечен контакт со семејството и со другите роднини (телефон, интернет - комуникатор и е-пошта), и доколку е потребно давање помош во справување со итни службени работи преку е-пошта или телефон.

вање на вработувањето на медицински сестри и негуватели на една установа и воведување смени на работници. Повеќекратното вработување е еден од проблемите на полскиот систем за долгорочна нега и здравствена заштита. Медицинските сестри и негувателите се малку платени, па затоа често се вработуваат во неколку установи со цел да ги задоволат основните животни потреби.

Другите превентивни мерки беа поврзани со следење на здравствениот статус и нега на згрижените лица. Воведено е мерење на температурата на работниците и на згрижените. Заштитната опрема (маски, ракавици, дезинфекција на простории) стана задолжителна. Понатаму, домовите за социјална помош го сменија начинот на организирање активности за жителите. Рехабилитационите услуги и активностите кои вклучуваат персонал надвор од објектот беа укинати со цел да се намалат контактите со надворешниот свет и ризикот од пренесување на инфекција во установата. Активностите во рамките на објектот беа организи- рани во редовни, мали групи. Во текот на летото беа промовирани активности надвор од теренот на единиците за згрижување (во градините). Понатаму, социјалните контакти на жителите со нивните семејства беа ограничени на телефонски повици, он-лајн разговори или посети на подготвени простори, со стакло помеѓу сместените во домовите и нивните посетители ${ }^{2}$. Очигледно, додека се намалува ризикот од пренесување на КОВИД-19, ограничувањето на активностите и социјалниот контакт може негативно да влијае врз здравствениот статус, односно ограничување на пристапот до рехабилитација на психолошката состојба на згрижените лица.

Мерките за интервенција донесени од установи за нега а стари лица вклучуваат изолација на жители со симптоми кои можат да бидат поврзани со КОВИД-19 и пациенти со потврдена инфекција. Резидентите кои влегуваат во дом за социјална помош по болничка

2 https://www.gov.pl/web/rodzina/dobrepraktyki-domow-pomocy-spolecznej-wczasie-pandemii 
нега, исто така, требаше да бидат тестирани на КОВИД-19 и изолирани 10 дена. Во случај на потреба за трансформација на жителите во болници поради КОВИД-19, во многу случаи армијата интервенира и помага при евакуација.

Централната влада, покрај консултациите и промовирањето на препораките за превентивни процедури во нега во установи за згрижување стари лица, презеде активности за поддршка на вработените и за опремување на единици за згрижување, иако реакцијата на политиката и регулативата варираа помеѓу двата сектора: здравствена и социјална.

Во здравствениот сектор, регулативите за единиците за медицинска нега и грижа, во однос на постапките за превенција беа исти како и во другите здравствени единици и беа вклучени тестирање, изолација, единствено вработување на персонал и карантин на персонал со ризик од инфекција и пренесување на вирусот SARS CoV-2 поради директен контакт со болно лице. Законот за посебни решенија поврзани со спречување, борба и сузбивање на КОВИД-19, други заразни болести и кризни ситуации предизвикани од нив од 2 март 2020 година (Ustawa z dnia 2 marca 2020 r. o szczególnych rozwiązaniach związanych $z$ zapobieganiem, przeciwdziataniem $i$ zwalczaniem COVID-19, innych chorób zakaźnych oraz wywołanych nimi sytuacji kryzysowych), воведе надоместок за медицинскиот персонал во карантин поради COVID-19 еднаков на 100\% од платата во здравствениот сектор, создавајќи нееднаквости помеѓу вработените во здравствениот и социјалниот сектор, додека редовна стапка на надоместок во случај на болест (80\%) не е променета. Во исто време - соочувајќи се со недостиг од вработување - работниците во многу случаи морале да ги извршуваат своите должности додека биле во карантин. На овие нееднаквости силно се спротивставија синдикатите на социјалните работници.

Во социјалниот сектор, дополнителни финансиски средства беа посветени на привремено зголемување на платата на вработените. Сепак, синдикатите привлекуваа внимание на фактот дека не сите вработени во установи за долгорочна нега добија плата навреме и на нееднаквостите во условите за работа и платите помеѓу вработените во медицинската сестра и здравствената заштита во здравствениот и социјалниот сектор. Финансиските ресурси, најмногу од Европскиот социјален фонд, беа искористени и за подобрување на пристапот до превентивна опрема (т.е. маски, ракавици, комбинезони) и за приспосбување на просториите заради зголемување на епидемиолошката безбедност.

\section{Заклучоци}

Неочекуваната пандемија имаше силно влијание врз установите за долготрајно згрижување постари лица, укажувајќи на неразвиеноста на секторот, изложување на неговите не- 
совршености и недостатоци и конечно резултирајќи во привлекување на вниманието на јавноста кон проблемите сна обезбедувањето грижа за постари и инвалидни лица, неспособни за самостоен живот.

Првата реакција на пандемијата беше доста хаотична, ескалирана поради недостиг од координација помеѓу здравствениот систем и системот за социјалната помош што резултираше со слаб пристап до медицински посети и тестови за КОВИД-19 и за персоналот и за сместените лица во институциите за нега на стари лица Не само што беше долгорочна, туку болничката нега се соочи со тешкотии поради високо ниво на инфекции во текот на првиот месец од пандемијата. Недостигот од медицински сестри и на персоналот за нега, нивното слабо препознавање и престиж, како и ниските примања беа меѓу причините за повеќе вработувања, што пак придонесе за пренесување на вирусот до единиците за институционална нега. Овој проблем беше делумно решен со усвојување на правило за зголемување на платите и единствено вработување, но само привремено, додека се потребни долгорочни решенија бидејќи популацијата на медицински сестри старее, а потребите за долгорочна нега само ќе се зголемуваат.

Пандемијата стимулира дискусија за потребата од деинституционализација во долгорочната грижа, за што особено се залагаат претставниците на инвалидите. Потребна е деинституционализација, сфатена како развој на домашни услуги, иако имајќи ги предвид промените во општеството, семејните промени и ниската стапка на плодност, грижата за живеење е решение што сѐ уште е потребно и во месеците што претходеа на пандемијата побарувачката за услуги беше многу поголема отколку што може да ги исполнат институционалните способности на субјектите од јавниот сектор. Пандемијата може да ја намали оваа побарувачка од една страна и да влијае врз квалитетот на обезбедените услуги од друга страна, со повисоки хигиенски стандарди.

Конечно, службите за нега за згрижување стари лица треба да се прошират на поголема популација и да се обезбедат највисоки санитарни стандарди. Есента, кога инфекциите со КОВИД-19 почнаа рапидно да растат, се зголеми загриженоста не само за домовите за долготрајно згрижување, туку и за негата на постари и инвалидни лица кои може да се соочат со тешкотии поради висок ризик од инфекција или да останат без помош ако нивното семејство- негувателите се разболат. Дебатата се насочува кон воспоставување не само на поддршка на институциите, каде што сѐ уште се јавува инфекција, туку и за воспоставување механизам за обезбедување помош на постари лица 
и за зависни луѓе дома, кои, исто така, се изложени на висок ризик од негативни последици од пандемијата.

\section{Користена литература:}

Comas-Herrera A., Ashcroft E.C., Lorenz-Dant K. (2020), International examples of measures to prevent and manage COVID-19 outbreaks in residential care and nursing home settings, International Long-term Care Policy Network, https://ltccovid.org/wp-content/ uploads/2020/05/International-measures-to-prevent-and-manage-COVID19-infectionsin-care-homes-11-May-2.pdf [downloaded October 3rd 2020]

Golinowska S., Sowa-Kofta A. (2017), Imbalance between demand and supply of long-term care. The case of post-communist Poland. In: The Routledge Handbook of Social Care Work Around the World, Routledge

Rządowe Centrum Bezpieczeństwa (2020), Report COVID-19 Sytuacja epidemiologiczna w Polsce i na świecie. Stan na 8 czerwca 2020 godz. 13:30, Warszawa

Szatur-Jaworska B. (2016), Polska polityka społeczna wobec starzenia się ludności w latach 1971-2013, Instytut Polityki Społecznej Uniwersytet Warszawski, Warsaw

Szatur-Jaworska B. (2018), Polityka senioralna - nowa czy stara polityka publiczna w Polsce? in: Polityka społeczna w Polsce. Osiagnięcia i wyzwania, Bednarski M., Wiśniewski Z. (ed), Komitet Nauk o Pracy i Polityce Społecznej PAN, Instytut Pracy i Spraw Socjalnych, Warszawa. 